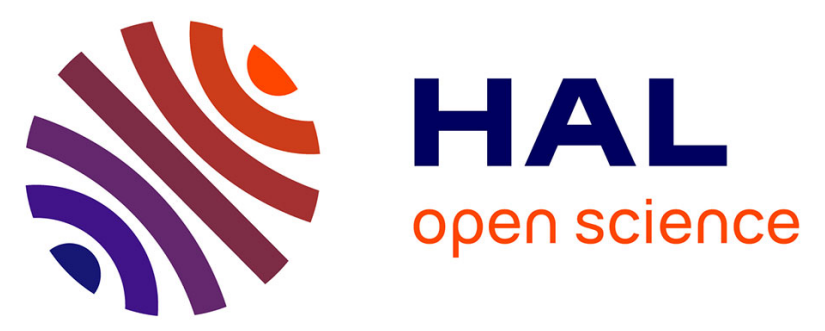

\title{
Incorporation and stability of carotenoids in a functional fermented maize yogurt-like product containing phytosterols
}

Magali Gies, Adriana Maria Descalzo, Adrien Servent, Claudie Dhuique-Mayer

\section{- To cite this version:}

Magali Gies, Adriana Maria Descalzo, Adrien Servent, Claudie Dhuique-Mayer. Incorporation and stability of carotenoids in a functional fermented maize yogurt-like product containing phytosterols. LWT - Food Science and Technology, 2019, 111, pp.105 - 110. 10.1016/j.lwt.2019.04.103 . hal03486755

\section{HAL Id: hal-03486755 \\ https://hal.science/hal-03486755}

Submitted on 20 Dec 2021

HAL is a multi-disciplinary open access archive for the deposit and dissemination of scientific research documents, whether they are published or not. The documents may come from teaching and research institutions in France or abroad, or from public or private research centers.
L'archive ouverte pluridisciplinaire HAL, est destinée au dépôt et à la diffusion de documents scientifiques de niveau recherche, publiés ou non, émanant des établissements d'enseignement et de recherche français ou étrangers, des laboratoires publics ou privés.

\section{(ㄷ)(1) $\$$}

Distributed under a Creative Commons Attribution - NonCommerciall 4.0 International 
1 Incorporation and stability of carotenoids in a functional fermented maize yogurt-like product containing phytosterols

Magali Gies $^{\mathrm{a}, \mathrm{b}}$, Adriana Maria Descalzo ${ }^{\mathrm{c}}$, Adrien Servent ${ }^{\mathrm{a}, \mathrm{b}}$, Claudie Dhuique-Mayer $^{\mathrm{a}, \mathrm{b}}$

${ }^{a}$ Centre de Coopération Internationale en Recherche Agronomique pour le Développement

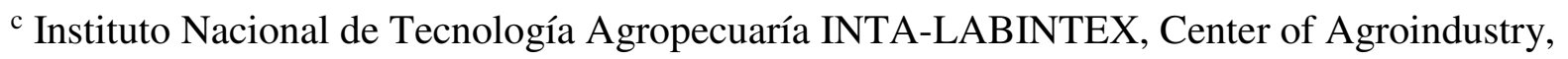




\section{Abstract}

A functional yogurt-like product based on fermented maize enriched in carotenoids and phytosterols was developed to be an alternative to existing functional dairy products. Incorporation and stability of fat-soluble compounds were challenging in this complex matrix. Moreover, it is known that phytosterols decrease carotenoids absorption, but this decline can be offset by increasing carotenoids in foodstuffs. Thus, the aims of this work were to optimize the manufacturing process of a fermented yogurt-like product containing phytosterols by incorporating carotenoids taking into account two Lactobacilli strains as starters. The stability of $\beta$-cryptoxanthin, $\beta$-carotene and lycopene was studied during the whole process in order to confer a nutritional balance between them and phytosterols. After $15 \mathrm{~h}$ of fermentation, a starter ratio 50-50 (L. plantarum-L. casei) gave the best final biomass with $10^{9} \mathrm{CFU} / \mathrm{g}$ necessary to obtain a probiotic potential. Relative carotenoid losses $(20-27 \%)$ occurred during the pasteurization step while no negative impact on carotenoids was due to fermentation. Fat-soluble compounds remained relatively stable during the whole process with $75 \%$ of retention. These results suggest that incorporation and stability of carotenoids in a fermented-maize yogurt-like product containing phytosterols are necessary steps to induce a cholesterol-lowering effect without detrimental effects on carotenoids.

\section{Keywords}

Fermented-maize; Probiotic cereal product; Fat-soluble phytomicronutrients; $\beta$-carotene; $\beta$-sitosterol 


\section{Introduction}

The increasing demand of consumers for healthy food has reinforced the necessity to design new functional foods. A functional food containing bioactive compounds can enhance health or reduce the risk of diseases (Prado, Parada, Pandey, \& Soccol, 2008; I. Salmerón, 2017; Serafini, Stanzione, \& Foddai, 2012). Among functional foods, dairy products with incorporation of fat-soluble compounds (e.g. phytosterols) and fatty acid omega 3, or addition of probiotic starters represent 60 to $70 \%$ of the functional foods market (Ivan Salmerón, Thomas, \& Pandiella, 2015; Chen, McClements, \& Decker, 2013). However, lactose intolerance or protein allergies and cholesterol content are factors that have recently increased the demand for non-dairy products (Prado et al., 2008). Cereal-based products are a general response to consumers for health benefits and as an alternative to dairy products (Marsh, Hill, Ross, \& Cotter, 2014) by being both probiotic (living microorganisms $10^{8}$ to $10^{9}$ cells per gram of consumed product) and containing fibers, minerals and vitamins (Kandylis, Pissaridi, Bekatorou, Kanellaki, \& Koutinas, 2016).

However, there is a lack of available data in the literature about cereal-based fermented foods with incorporation of phytosterols and/or carotenoids. Chen et al. (2013) described the importance of added carotenoids in functional foods for their positive impact on health problems. The authors also reported the challenges associated with the incorporation of these fat-soluble compounds, because of their poor water solubility, their high sensitivity to oxidation and their structural and physico-chemical properties. It is important that these dietary molecules remain stable during the whole process, transport and storage, in order to maintain their potential bioactivity and a high bioavailability during digestion to be efficient on health. 
Among carotenoids, $\beta$-carotene and $\beta$-cryptoxanthin are pro-vitamin $\mathrm{A}$, known to help the organism to maintain normal eye health, epithelial function, embryonic development and immune system function (Stephensen, 2001). Beside these carotenoids, lycopene, which is a non-provitamin A carotenoid, has some other health benefits, such as decreasing the development of prostate, cervical, colon, rectal, stomach and other types of cancers (Giovannucci, 1999). This carotenoid is also known for its great antioxidant activity (Fiedor \& Burda, 2014). Moreover, supplementing functional food containing phytosterols with carotenoids seems necessary because it is suggested that phytosterols reduce the incorporation of carotenoids into mixed micelles during the first steps of digestion (Baumgartner, Ras, Trautwein, Mensink, \& Plat, 2017). Furthermore, the competition between phytosterols and $\beta$ carotene (which is the most important pro-vitamin A micronutrient) during intestinal absorption has been reported by Fardet, Morise, Kalonji, Margaritis, \& Mariotti (2015).

From another side, carotenoid stability must be performed during food processing such as pasteurization and fermentation. The degradation of carotenoids and especially $\beta$-carotene during food processing is mainly due to oxidation and thermal treatments knowing that $\beta$ carotene oxidation generates losses of color and pro-vitamin A activity (Pénicaud, Achir, Dhuique-Mayer, Dornier, \& Bohuon, 2011). Considering fermentation process, some strains such as Lactobacillus plantarum can enhance the nutritional value of fermented food by increasing the nutrient density (mostly due to their consumption of sugar), hydrolyzing polymers from the raw material, biosynthesizing bioactive peptides, degrading toxic or antinutritional factors and by synthetizing promoters for absorption (Septembre-Malaterre, Remize, \& Poucheret, 2018).

Recently, Descalzo et al. (2018) have developed a traditional fermented maize yogurt-like product derived from an African preparation, with added phytosterols. The authors suggested 
adding carotenoids from natural fruits to increase the bioactive potential of the yogurt-like product. They also proposed to turn the product probiotic with pertinent strains and to use dispersible phytosterols instead of esterified phytosterols emulsion because of the lipid oxidation due to the presence of unsaturated fatty acids in the esterified formulation. Finally in this work, the manufacturing process should have been standardized in fermenters by monitoring temperature and $\mathrm{pH}$ parameters during pasteurization and fermentation steps as it was advised by Marsh et al. (2014).

Consequently, this paper focuses on the standardization of a fermented functional product by incorporating carotenoids such as $\beta$-cryptoxanthin, $\beta$-carotene and lycopene in a fermentedmaize yogurt-like product containing dispersible phytosterols. Specifically our aims were (1) to optimize the manufacturing process of this product containing phytosterols by incorporating natural carotenoids from papaya/melon fruit extracts before pasteurization step; (2) to improve the fermentation of the product with a selection of Lactobacilli starters in order to obtain a probiotic potential; (3) to study the behavior of these fat-soluble compounds during the whole process in order to determine which step has the main impact on their stability. In fine, the aim was obtaining a balanced product with carotenoids and phytosterols giving an interesting nutritional value and a cholesterol-lowering potential to this maize fermented yogurt-like product.

\section{Materials and methods}

\subsection{Bacterial strains and inocula preparation}

Two pure lyophilized strains Lactobacillus plantarum (Lp352-S1616 / CNCM I-3069) and Lactobacillus casei (Lc1 S42-2015 / CNCM I-4592) were provided as starters by Ennolys- 
Lesaffre (Marq-en-Baroeul, France) and stored under vacuum pack at $+4^{\circ} \mathrm{C}$. Individual strains and a $50-50 \%$ ratio (L. plantarum - L. casei) were inoculated at $1 \cdot 10^{6} \mathrm{CFU} / \mathrm{g}$ in the maizebased matrix.

\subsection{Manufacture of the maize-based matrix}

The manufacturing process including maize soaking, crushing, sieving, formulation, pasteurization and lactic fermentation was described in Figure 1. $100 \mathrm{~g}$ of maize grains from a French local market were soak and then crushed at $5000 \mathrm{rpm}$ for $1 \mathrm{~min}$ (Retsch Grindomix GM 200, Germany). Ingredients such as $3.6 \%$ of sugar (Daddy, France) and $2.4 \%$ of semiskimmed powdered milk (Régilait, France) were added in the maize juice among others. Commercial dispersible phytosterols (Vitaesterol ${ }^{\circledR}$ S-80 WDP $90 \%$ non GMO with $80 \%$ of $\beta$-sitosterol, Vitae Naturals, Spain) were added. Freeze-dried papaya (Carica papaya var. Formosa, Brazil) and melon (Cucumis melo var. Cantalupensis, France) were incorporated as sources of carotenoids ( $\beta$-cryptoxanthin - lycopene and $\beta$-carotene respectively). Pasteurization and fermentation were performed in a six-hundred-milliliter glass double wall fermenter (Legallais, France) as described by de J. C. Munanga, Loiseau, Grabulos, \& Mestres (2016). The intern temperature and $\mathrm{pH}$ were determined per minute by food penetration probes connected with a central data acquisition (Almemo® 2690-8A, Ahlborn, Germany). After pasteurization, the lactic fermentation started with Lactobacilli strains added either pure or mixed (50-50 ratio) at a concentration of $1 \cdot 10^{6} \mathrm{CFU} / \mathrm{g}$. Fermentations were conducted at $37 \pm 0.2{ }^{\circ} \mathrm{C}$ for $15 \mathrm{~h}$. The products were kept frozen and in darkness at $-20{ }^{\circ} \mathrm{C}$ until analyses. 


\subsubsection{Determination of growth kinetics}

150

The number of Lactobacilli was estimated each hour during fermentation by plating on MRS agar medium (Biokar Diagnotics, France - Ref BK089HA) at $37 \pm 0.2{ }^{\circ} \mathrm{C}$ for $48 \mathrm{~h}$. Growth kinetics and $\mathrm{pH}$ values were then associated to each bacteria or ratio. Growth parameters were calculated: specific growth rate $\left(\mu_{\max }\right)$ and generation time corresponding to $G=\ln (2) / \mu_{\max }$. Growth kinetics were determined and modelled in agreement with the Rosso equation:

$$
\log N_{(t)}= \begin{cases}\log N_{0} & \text { si } t<\lambda \\ \log N_{\max }-\log \left(\left[1+\left(\frac{N_{\max }}{N_{0}}-1\right) \exp \left(-\mu_{\max }(t-\lambda)\right)\right]\right) & \text { si } t \geq \lambda\end{cases}
$$

where $\mu_{\max }$ is the specific growth rate $\left(\mathrm{h}^{-1}\right), \lambda$ the latency period $(\mathrm{h}), \mathrm{N}_{0}$ the initial population (CFU/g), $\mathrm{N}_{\max }$ the maximal population (CFU/g) and log the decimal logarithm.

\subsubsection{Determination of the final bacterial ratio}

In order to determine the final ratio of 50-50 ratio after $15 \mathrm{~h}$ of fermentation the strains were differentiated by their sugar consumption with an API 50 CHL gallery (Analytical Profile Index - Biomérieux, France). Then, a 50 CHL agar medium commercialized (Biomérieux, France) was used with $16 \mathrm{~g} / \mathrm{L}$ added agar-agar. A control was made without any sugar, although two others were made with $20 \mathrm{~g} / \mathrm{L}$ added glucose (Glc medium) and $20 \mathrm{~g} / \mathrm{L}$ added arabinose (Ara medium). Just at the end of the fermentation, $1 \mathrm{~g}$ of the product was sampled and diluted from $10^{-1}$ to $10^{-8} .100 \mu \mathrm{L}$ of the dilutions $10^{-6}, 10^{-7}$ and $10^{-8}$ were sowed on the control medium, the Glc and the Ara mediums and incubated during $48 \mathrm{~h}$ at $37 \pm 0.2{ }^{\circ} \mathrm{C}$. 
171 Just after pasteurization, $1 \mathrm{~g}$ of the product was sampled and diluted from $10^{-1}$ to $10^{-4} .100 \mu \mathrm{L}$ 172 of each dilution were sowed on Plate Count Agar (PCA) medium in triplicates and incubated 173 during $72 \mathrm{~h}$ at $30 \pm 0.2^{\circ} \mathrm{C}$ according to the ISO 4833-2:2013 Afnor norm.

\subsection{Proximate analysis}

175

The food composition of the product was analyzed in terms of proteins, lipids and carbohydrates contents. Proteins were measured following Kjeldahl method (AOAC- 2001), (N X 6.25) using a Foss Techator Digester and an automatic Foss analytical AB KjeltecTM 8400 apparatus (Foss, Sweden). Lipid content was obtained with the Folch extraction procedure (Schäfer, 1998). Starch was dosed according to Clegg (1956) with anthrone reagent method. Analysis and separation of soluble sugars were determined using an UPLC - 1290 System Infinity II (Agilent, USA) equipped with a refractometer detector. A SHODEX SH1011 column 300x8 mm (Tokyo, Japan) was used with an isocratic system of water with $\mathrm{H}_{2} \mathrm{SO}_{4}(0.01 \%)$ and a flow rate of $0.7 \mathrm{~mL} / \mathrm{min}$. Temperature was set at $30{ }^{\circ} \mathrm{C}$, injection volume at $10 \mu \mathrm{L}$ and spectrophotometric detection at 210 and $245 \mathrm{~nm}$. External calibration of glucose, fructose, lactose and sucrose were realized using standards from Sigma-Aldrich (France). Dry matters were obtained in a vacuum oven at $70{ }^{\circ} \mathrm{C}$ during $24 \mathrm{~h}$ according AOAC method 1991.

\subsection{Phytomicronutrients analysis}

Fat-soluble compounds such as carotenoids ( $\beta$-cryptoxanthin, $\beta$-carotene and lycopene), phytosterols ( $\beta$-sitosterol) and tocopherols ( $\alpha$-tocopherol and $\gamma$-tocopherol) were analyzed by UPLC-DAD. The fat-soluble extraction was adapted from Rossetti et al. (2010). Briefly, $1 \mathrm{~g}$ 
of product was saponified with $1.5 \mathrm{ml}$ of $12 \mathrm{~N} \mathrm{KOH}$ for $30 \mathrm{~min}$ at $70{ }^{\circ} \mathrm{C}$ and extracted twice with $5 \mathrm{~mL}$ of $\mathrm{n}$-hexane. Hexanic phases were evaporated under nitrogen and dissolved in 1 $\mathrm{mL}$ of a MTBE/methanol solution (4:1, v:v) before injection in UPLC system. An UPLC 1290 System Infinity II (Agilent, USA), with a diode array detector (DAD) and a fluorescence detector (FLD) was used. The column was a C30 YMC (150 x $4.6 \mathrm{~mm} ; 3 \mu \mathrm{m})$ (YMC Europe GMBH, Germany). Mobile phases were methanol as eluant A, water as eluant B and MTBE as eluant $\mathrm{C}$, set at $1.5 \mathrm{~mL} / \mathrm{min}$ flow rate. The gradient used to separate carotenoids, phytosterols and tocopherols was the following: 0-1.5 $\min [60 \% \mathrm{~A}, 40 \% \mathrm{~B}] ; 1.5-3 \min [80$ $\%$ A, $20 \% \mathrm{~B}] ; 3-12.5 \min [80 \% \mathrm{~A}, 5 \% \mathrm{~B}, 15 \% \mathrm{C}] ; 12.5-15 \min [15 \% \mathrm{~A}, 85 \% \mathrm{C}] ; 15-17$ $\min [100 \% \mathrm{~A}]$ and back to the initial conditions for re-equilibration. The column temperature was $20{ }^{\circ} \mathrm{C}$ and the injection volume was $10 \mu \mathrm{L}$. Detection was set at $210 \mathrm{~nm}$ (DAD) for phytosterols, 450 and $470 \mathrm{~nm}$ (DAD) for carotenoids. Fluorescence detection (FLD) for tocopherols was set at $296 \mathrm{~nm}$ (excitation) and $330 \mathrm{~nm}$ (emission). Quantification was achieved using calibration curve with $\beta$-carotene, $\beta$-cryptoxanthin, lycopene (Extrasynthese, France), $\alpha / \gamma$-tocopherols standards (Sigma $S^{t}$ Louis, USA) and $\beta$-sitosterol standard (Supelco, Bellefonte,USA).

\section{Statistical analyses}

All statistical analyses were performed using XLSTAT software version 19.6 (Addinsoft, France). All data were reported as means \pm standard deviation (SD) from three replicates of each experiment. Data were analyzed statistically using one-way analysis of variance (ANOVA) in order to determine significant differences $(\mathrm{p}<0.05)$. Tukey's multiple comparison method was used to further examine any significant difference between results. 
2. Results and discussion

217

218

219

220

221

222

223

224

225

226

227

\subsection{Standardisation of the manufacturing process with incorporation} of carotenoids

According to the manufacturing process (Figure 1), the standardization in fermenters was conducted to monitor pasteurization conditions and microbial parameters during fermentation. This optimization of batch fermentation allowed a better control of parameters such as temperature and $\mathrm{pH}$, thus predicting kinetics bacterial growth and ensuring product safety. A model of fermentation of a traditional Beninese beverage called gowé using this batch fermentation was described by de J. C. Munanga et al. (2016). The incorporation of lyophilized fruits enhanced the homogeneity of the product just as dispersible phytosterols. Moreover, this form of fruit concentrate was recommended as functional food ingredients because its richness in antioxidant bioactive compounds and dietary fibers (Rocha, FávaroTrindade, \& Grosso, 2012). The addition of bioactive compounds like carotenoids led to a fortification in fat-soluble pro-vitamin $\mathrm{A}$ as well as antioxidants. This carotenoids supplementation induced a functional equilibrium with a balanced ratio between carotenoids and phytosterols, which should have no detrimental impact on carotenoids absorption.

In order to obtain a probiotic functional product, the cooking step was set before fermentation, acting as pasteurization in our present study. In that case, after the pasteurization, the sterility test on PCA proved that the product was microbiologically stable and safe with only $3.33 .10^{1}$ $\mathrm{CFU} / \mathrm{g}$ which entered in the Afnor norm.

In regard to the nutritional composition of the functional product, the macronutrient contents were reported in Table 1. The product is balanced in proteins, lipids and sugars. It contained 
twice more proteins and $30 \%$ less sugars than a dairy yogurt containing fruits, regarding the table of the USDA (2018). Dry matter was $21.3 \pm 0.01 \%$ and the calorific value $121.64 \pm 6.08$ $\mathrm{kcal} / 100 \mathrm{~g}$.

\subsection{Selection of starters and microbiological optimization of the} functional product

In order to select the starters to initiate the fermentation, the kinetic growth, the latency period, the final $\mathrm{pH}$ and the final biomass were compared between different strains $L$. casei versus L. plantarum versus their ratio 50-50. Therefore, these strains were used either pure or mixed in a ratio $50-50$.

Data were modelled in agreement with Rosso model (1) on Figure 2. Strains fermented into the maize-based matrix until reaching the stationary phase around $15 \mathrm{~h}$, by increasing three times their biomass from $1 \cdot 10^{5}-1.10^{6} \mathrm{CFU} / \mathrm{g}$ to $1 \cdot 10^{9}-1 \cdot 10^{9,5} \mathrm{CFU} / \mathrm{g}$. Thus, the final product contained enough living Lactobacilli at the end of the process to be potentially probiotic, that is to say more than $10^{9} \mathrm{UFC} / \mathrm{g}$ (Prado et al., 2008). All the final products had a $\mathrm{pH}$ between 4 and 4.8; it is the known $\mathrm{pH}$ for classic yogurt $(\mathrm{FAO}, 1995)$ and could guarantee its shelf life by insuring a low contamination rate as well as its microbiological stability. Moreover, the latency period of the 50-50 ratio is only $3 \mathrm{~h}$ (against $4 \mathrm{~h}$ and $5 \mathrm{~h}$ for $L$. plantarum and $L$. casei respectively) with a specific growth rate reaching $0.94 \mathrm{~h}^{-1}$ (Table 2). Thus, this ratio ensures a brief fermentation start with a swift exponential growth. Moreover, multistrain or multispecies probiotic beverages may provide greater beneficial effects than monostrain cultures (Marsh et al., 2014). L. plantarum was chosen for its ubiquity: it is found in the environment, especially on plants and therefore on maize. L. casei species are known to be used in a lot of probiotic dairy products. Consequently, the 50-50 ratio is the best compromise to ferment the maize-based product, regarding to the microbiological results. 
In order to determine the real final ratio of strains, the two Lactobacilli strains have been counted individually at the end of the fermentation. The API 50 CHL gallery showed that the final ratio was around $45 \%$ of L. plantarum and $55 \%$ of $L$. casei which is highly correlated with the kinetic growth. Regarding those results, there is no competition for nutrients between these two strains: they kept their initial ratio and their own probiotic potential.

\subsection{Carotenoids content and other fat-soluble phytomicronutrients} in the functional yogurt-like product

Carotenoids, tocopherols and $\beta$-sitosterol were quantified in the functional yogurt-like product and reported in Table 1. Three main carotenoids were found in the final product: $\beta$ cryptoxanthin and lycopene related to papaya lyophilized extract and $\beta$-carotene from melon lyophilized extract. The major carotenoids were pro-vitamin A $\beta$-carotene and the well-known antioxidant carotenoid called lycopene. The total carotenoids content of the product was 16 $\mathrm{mg} / \mathrm{kg}$ representing $2.01 \pm 0.14 \mathrm{mg}$ per serving portion of $125 \mathrm{~g}$. This high content of carotenoids also produced the final orange color of this food. Using the retinol activity equivalent (RAE) as an estimation of vitamin A in the product, $125 \mathrm{~g}$ would bring $12 \%$ of the Recommended Daily Allowance (RDA) for an adult. Moreover, approximately $2 \mathrm{mg}$ of carotenoids per portion is enough to counteract the competition for micellarization of carotenoids with phytosterols during digestion. Consequently, it is recommended to increase carotenoids intake during phytosterols consumption (Fardet et al., 2015; Noakes et al., 2002). Tocopherols originated from fruit extracts bring $4 \%$ of RDA vitamin E. These fat-soluble compounds are antioxidants in vivo for metabolism functions and also efficient for the protection of other phytomicronutrients against oxidative damage. $\alpha$-tocopherols represented $0.34 \pm 0.04 \mathrm{mg} / \mathrm{kg}$ and $\gamma$-tocopherols $3.47 \pm 0.30 \mathrm{mg} / \mathrm{kg}$. In fine, one portion of $125 \mathrm{~g}$ of the 
yogurt-like product contained $2.5 \mathrm{~g}$ of free phytosterols (mainly $\beta$-sitosterol). This content is enough to obtain a cholesterol-lowering effect. Indeed, according to the report of ANSES (2014), an ingestion of $2 \mathrm{~g}$ of phytosterols per day is the approximate effective dose essential to reduce the Low-Density Lipoprotein cholesterol (LDL-cholesterol) concentration in plasma.

\subsection{Stability of fat-soluble phytomicronutrients during the} manufacturing process

Carotenoids and tocopherols stability were studied during pasteurization and fermentation process. To evaluate the effect of lactic fermentation on carotenoid content, the yogurt-like product was first fermented with L. plantarum or L. casei during 10, 15 and $20 \mathrm{~h}$. After $20 \mathrm{~h}$ of fermentation with L. casei, lycopene significantly ( $<$ < 0.05) increased from 5.1 to $7.7 \mathrm{mg} / \mathrm{kg}(+33 \%), \beta$-carotene from 6.9 to $7.4 \mathrm{mg} / \mathrm{kg}(+7 \%)$ and tocopherols from 5.1 to $7.2 \mathrm{mg} / \mathrm{kg}(+30 \%)$. No changes were observed for tocopherols when the product was fermented with $L$. plantarum and a smaller increase occurred for $\beta$-carotene (from 8 to 9.2 $\mathrm{mg} / \mathrm{kg} ;+13 \%)$ but no significant increase for lycopene. Together, these results supported that fermentation allowed the recovery of carotenoids and tocopherols to a significant extent particularly when the product was fermented with the starter $L$. casei. It was probably due to a production of enzymes like lipases or proteinases by strains, which allowed the liberation of carotenoids from complexes, then permitted a better extractability of these compounds. Moreover, it is also possible that these Lactobacilli strains demonstrated a carotenogenesis, when they are not in co-culture, as it is described by Kot, Błażejak, Gientka, Kieliszek, \& Bryś (2018) and Kot, Błażejak, Kurcz, Gientka, \& Kieliszek (2016). The increase of nutritional value and the changes in bioactive compound contents over lactic fermentation were reported by Katina et al. (2007) and recently by Septembre-Malaterre et al. (2018). The 
proteolytic activity of lactic acid bacteria culture could result in a better recovery of carotenoids. By disrupting the protein-carotenoid complexes in vegetables, carotenoid extraction was improved (Bhaskar, Suresh, Sakhare, \& Sachindra, 2007). All these results represented another argument to support the choice of the fermentation with the 50-50 ratio of strains.

Considering this ratio of starters, the fat-soluble phytomicronutrient contents were then analyzed at three different steps of the manufacturing process: raw product (neither pasteurized nor fermented), pasteurized product and final product pasteurized and fermented for $15 \mathrm{~h}$. The Figure 3 describes the evolution of bioactive compounds in the fermented product obtained with the 50-50 ratio. While carotenoids were slightly impacted during pasteurization, tocopherols and phytosterols remained stable.

There were significant $(\mathrm{p}<0.05)$ losses in carotenoids after pasteurization but no significant difference between the pasteurized product before and after $15 \mathrm{~h}$ of fermentation. Indeed, the averages of losses after pasteurization were $21.4 \pm 6.0 \%, 26.9 \pm 6.0 \%$ and $20.2 \pm 7.0 \%$ for $\beta$-cryptoxanthin, $\beta$-carotene and lycopene respectively; while the losses after $15 \mathrm{~h}$ of fermentation was $23.2 \pm 1.0 \%, 28.1 \pm 1.0 \%$ and $19.2 \pm 3.0 \%$. Therefore, in this case, $\beta$ carotene was more sensitive to the pasteurization step than $\beta$-cryptoxanthin and lycopene. The lower thermal degradation of lycopene, compared to other carotenoids, was generally observed in vegetable matrix (tomato, citrus juice) because lycopene is bounded with proteins, giving it a better structural protection (Achir, Hadjal, Madani, Dornier, \& DhuiqueMayer, 2015). Moreover, the lycopene degradation was also reported to be lower in lyophilized fruit form than in model system (Rocha et al., 2012).

It means that there is a "pasteurization effect" which represents the whole "process impact" on the bioactive compounds, because there is no "fermentation impact". Thus, the fermentation of lactic strains did not impact the stability of the compounds, probably because 
these bacteria released bioactive peptides improving the antioxidant capacity of the product (Septembre-Malaterre et al., 2018). Even with these relative losses of carotenoids after pasteurization (20 to $27 \%$ ), all fat-soluble compounds remained relatively stable during the whole process with a high level of retention (between $73 \%$ and $100 \%$ ). Note that cisisomerisation of $\beta$-carotene represents $6.5 \%$ of total $\beta$-carotene and this low percentage of isomerization did not really affect the concentration of $\beta$-carotene during the process. In the final product, the cis-isomerization of the lycopene reaches $10 \%$, with the half formed during pasteurization. Similar results on carotenoids degradation in pumpkin puree was observed by Provesi, Dias, \& Amante (2011) with a carotenoid retention > $75 \%$. According to Pinheiro Sant'Ana, Stringheta, Cardoso Brandão, \& Cordeiro de Azeredo (1998), a water pasteurization without pressure, exactly what was performed in this new formulation, is the best way to keep the most of carotenoids, between 56 and $89 \%$.

\section{Conclusion}

The standardization of this yogurt-like product, presented here as a generic functional fermented food, demonstrated that incorporation and stabilization of fat-soluble phytomicronutrients during a whole process is possible in a probiotic cereal-based product. Moreover, the nutritional balance between phytosterols and carotenoids was respected, to provide potential health effects such as a reduction of the absorption of cholesterol during digestion and a non-negligible intake of pro-vitamin A. Indeed, only the pasteurization step had a relative impact on carotenoids. The fermentation with the 50-50 ratio of L. plantarum and $L$. casei had no significant impact on the content of fat-soluble compounds. In the contrary, it seems that pure strains could demonstrate carotenogenesis. Finally, the 50-50 ratio presented the best growth parameters into this matrix and it is known that a co-culture is always better to enhance a probiotic potential. Further researches are needed in order to 
optimize this product on nutritional value. It is essential to know better this new cereal fermented yogurt-like product in terms of nutritional and sensory qualities. In that purpose, carotenoid bioaccessibility in this matrix has to be assessed in the future, just as sensory analyses.

\section{Acknowledgments}

We particularly would like to thank Ennolys-Lesaffre for providing the L. plantarum (CNCM I-3069) and the L. casei (CNCM I-4592). All our gratitude to Sylvie Lortal (Institut National de la Recherche Agronomique (INRA), UMR Science et Technologie du Lait et de l'Euf (STLO), 35000 Rennes, France) for her priceless help for this work.

\section{References}

Achir, N., Hadjal, T., Madani, K., Dornier, M., \& Dhuique-Mayer, C. (2015). Carotene Reactivity in Pink Grapefruit Juice Elucidated from Model Systems and Multiresponse Modeling. Journal of Agricultural and Food Chemistry, 63(15), 3970-3979. https://doi.org/10.1021/acs.jafc.5b00509

ANSES. (2014). OPINION of the French Agency for Food, Environmental and Occupational Health \& Safety on Assessment of the risks and benefits of consuming food products fortified with phytosterols and phytostanols (No. 2010-SA-0057; p. 15). MaisonsAlfort: ANSES.

Baumgartner, S., Ras, R. T., Trautwein, E. A., Mensink, R. P., \& Plat, J. (2017). Plasma fatsoluble vitamin and carotenoid concentrations after plant sterol and plant stanol 
consumption: a meta-analysis of randomized controlled trials. European Journal of Nutrition, 56(3), 909-923. https://doi.org/10.1007/s00394-016-1289-7

Bhaskar, N., Suresh, P. V., Sakhare, P. Z., \& Sachindra, N. M. (2007). Shrimp biowaste fermentation with Pediococcus acidolactici CFR2182: Optimization of fermentation conditions by response surface methodology and effect of optimized conditions on deproteination/demineralization and carotenoid recovery. Enzyme and Microbial Technology, 40(5), 1427-1434. https://doi.org/10.1016/j.enzmictec.2006.10.019

Chen, B., McClements, D. J., \& Decker, E. A. (2013). Design of Foods with Bioactive Lipids for Improved Health. Annual Review of Food Science and Technology, 4(1), 35-56. https://doi.org/10.1146/annurev-food-032112-135808

Clegg, K. M. (1956). The application of the anthrone reagent to the estimation of starch in cereals. Journal of the Science of Food and Agriculture, 7(1), 40-44. https://doi.org/10.1002/jsfa.2740070108

de J. C. Munanga, B., Loiseau, G., Grabulos, J., \& Mestres, C. (2016). Modeling Lactic Fermentation of Gowé Using Lactobacillus Starter Culture. Microorganisms, 4(4), 44. https://doi.org/10.3390/microorganisms4040044

Descalzo, A. M., Rizzo, S. A., Servent, A., Rossetti, L., Lebrun, M., Pérez, C. D., ... Dhuique-Mayer, C. (2018). Oxidative status of a yogurt-like fermented maize product containing phytosterols. Journal of Food Science and Technology, 55(5), 1859-1869. https://doi.org/10.1007/s13197-018-3102-5

FAO. (1995). Le lait et les produits laitiers dans la nutrition humaine. In Collection FAO: Alimentation et nutrition: Vol. 28. Retrieved from http://www.fao.org/docrep/t4280f/T4280F00.htm\#Contents

Fardet, A., Morise, A., Kalonji, E., Margaritis, I., \& Mariotti, F. (2015). Influence of Phytosterol and Phytostanol Food Supplementation on Plasma Liposoluble Vitamins 
and Provitamin A Carotenoid Levels in Humans: An Updated Review of the Evidence. Critical Reviews in Food Science and Nutrition, 00-00. https://doi.org/10.1080/10408398.2015.1033611

Fiedor, J., \& Burda, K. (2014). Potential Role of Carotenoids as Antioxidants in Human Health and Disease. Nutrients, 6(2), 466-488. https://doi.org/10.3390/nu6020466

Giovannucci, E. (1999). Tomatoes, Tomato-Based Products, Lycopene, and Cancer: Review of the Epidemiologic Literature. JNCI Journal of the National Cancer Institute, 91(4), 317-331. https://doi.org/10.1093/jnci/91.4.317

Kandylis, P., Pissaridi, K., Bekatorou, A., Kanellaki, M., \& Koutinas, A. A. (2016). Dairy and non-dairy probiotic beverages. Current Opinion in Food Science, 7, 58-63. https://doi.org/10.1016/j.cofs.2015.11.012

Katina, K., Liukkonen, K.-H., Kaukovirta-Norja, A., Adlercreutz, H., Heinonen, S.-M., Lampi, A.-M., ... Poutanen, K. (2007). Fermentation-induced changes in the nutritional value of native or germinated rye. Journal of Cereal Science, 46(3), 348355. https://doi.org/10.1016/j.jcs.2007.07.006

Kot, A. M., Błażejak, S., Gientka, I., Kieliszek, M., \& Bryś, J. (2018). Torulene and torularhodin: "new” fungal carotenoids for industry? Microbial Cell Factories, 17(1). https://doi.org/10.1186/s12934-018-0893-z

Kot, A. M., Błażejak, S., Kurcz, A., Gientka, I., \& Kieliszek, M. (2016). Rhodotorula glutinis_-potential source of lipids, carotenoids, and enzymes for use in industries. Applied Microbiology and Biotechnology, 100(14), 6103-6117. https://doi.org/10.1007/s00253-016-7611-8

Marsh, A. J., Hill, C., Ross, R. P., \& Cotter, P. D. (2014). Fermented beverages with healthpromoting potential: Past and future perspectives. Trends in Food Science \& Technology, 38(2), 113-124. https://doi.org/10.1016/j.tifs.2014.05.002 
Noakes, M., Clifton, P., Ntanios, F., Shrapnel, W., Record, I., \& McInerney, J. (2002). An increase in dietary carotenoids when consuming plant sterols or stanols is effective in maintaining plasma carotenoid concentrations. The American Journal of Clinical Nutrition, 75(1), 79-86. https://doi.org/10.1093/ajcn/75.1.79

Pénicaud, C., Achir, N., Dhuique-Mayer, C., Dornier, M., \& Bohuon, P. (2011). Degradation of $\beta$-carotene during fruit and vegetable processing or storage: reaction mechanisms and kinetic aspects: a review. Fruits, 66(6), 417-440. https://doi.org/10.1051/fruits/2011058

Pinheiro Sant'Ana, H. M., Stringheta, P. C., Cardoso Brandão, S. C., \& Cordeiro de Azeredo, R. M. (1998). Carotenoid retention and vitamin A value in carrot (Daucus carota L.) prepared by food service. Food Chemistry, 61(1-2), 145-151. https://doi.org/10.1016/S0308-8146(97)00084-8

Prado, F. C., Parada, J. L., Pandey, A., \& Soccol, C. R. (2008). Trends in non-dairy probiotic beverages. Food Research International, 41(2), 111-123. https://doi.org/10.1016/j.foodres.2007.10.010

Provesi, J. G., Dias, C. O., \& Amante, E. R. (2011). Changes in carotenoids during processing and storage of pumpkin puree. Food Chemistry, 128(1), 195-202. https://doi.org/10.1016/j.foodchem.2011.03.027

Rocha, G. A., Fávaro-Trindade, C. S., \& Grosso, C. R. F. (2012). Microencapsulation of lycopene by spray drying: Characterization, stability and application of microcapsules. Food and Bioproducts Processing, 90(1), 37-42. https://doi.org/10.1016/j.fbp.2011.01.001

Rossetti L., Langman L., Grigioni G. M., Biolatto A., Sancho A. M., Comerón E., \& Descalzo A. M. (2010). Antioxidant status and odour profile in milk from silage or lucerne-fed cows. Australian Journal of Dairy Technology, 65(1), 3-9. 
Salmerón, I. (2017). Fermented cereal beverages: from probiotic, prebiotic and synbiotic towards Nanoscience designed healthy drinks. Letters in Applied Microbiology, 65(2), 114-124. https://doi.org/10.1111/lam.12740

Salmerón, Ivan, Thomas, K., \& Pandiella, S. S. (2015). Effect of potentially probiotic lactic acid bacteria on the physicochemical composition and acceptance of fermented cereal beverages. Journal of Functional Foods, 15, 106-115. https://doi.org/10.1016/j.jff.2015.03.012

Schäfer, K. (1998). Accelerated solvent extraction of lipids for determining the fatty acid composition of biological material. Analytica Chimica Acta, 358(1), 69-77. https://doi.org/10.1016/S0003-2670(97)00587-4

Septembre-Malaterre, A., Remize, F., \& Poucheret, P. (2018). Fruits and vegetables, as a source of nutritional compounds and phytochemicals: Changes in bioactive compounds during lactic fermentation. Food Research International, 104, 86-99. https://doi.org/10.1016/j.foodres.2017.09.031

Serafini, M., Stanzione, A., \& Foddai, S. (2012). Functional foods: traditional use and European legislation. International Journal of Food Sciences and Nutrition, 63(sup1), 7-9. https://doi.org/10.3109/09637486.2011.637488

Stephensen, C. B. (2001). V ITAMIN A, I NFECTION, AND I MMUNE F UNCTION*. Annual Review of Nutrition, 21(1), 167-192. https://doi.org/10.1146/annurev.nutr.21.1.167

USDA. (2018). USDA - Basic Report: 43261, Yogurt, fruit variety, nonfat. Retrieved from https://ndb.nal.usda.gov/ndb/foods/show/43261?fgcd=\&manu=\&format=\&count=\&m $\mathrm{ax}=25 \&$ offset $=\&$ sort $=$ default $\&$ order $=$ asc $\& q$ lookup $=$ soya + yogurt $\& d s=S R \& q \mathrm{t}=\& q p=\&$ $\mathrm{qa}=\& \mathrm{qn}=\& \mathrm{q}=\& \operatorname{ing}=$ 


\section{$1 \quad$ Figure captions}

2 - Figure 1: Schematic overview of the manufacturing process

3 - Figure 2: Growth kinetics with Rosso model and $\mathrm{pH}$ drop of fermented products with A)

$4100 \%$ L. plantarum; B) $100 \%$ L. casei; C) ratio 50-50 L. plantarum /L. casei

ᄃ- Rosso model; - $\mathrm{pH} ; \bullet-\log$ (biomass)

- Figure 3: Contents of carotenoids, tocopherols and $\beta$-sitosterol at different steps of the

$7 \quad$ process with $\mathrm{a}$ and $\mathrm{b}$ as different statistic groups $(\mathrm{p}<0.05)$;

$8 \quad$ Not pasteurized; $=$ Pasteurized, not fermented; $\quad$ - Fermented for $15 \mathrm{~h}$

9

10 
Figure 1

21

22

23

24

25

26

27

28

29

30

31

32

33

34

35

2

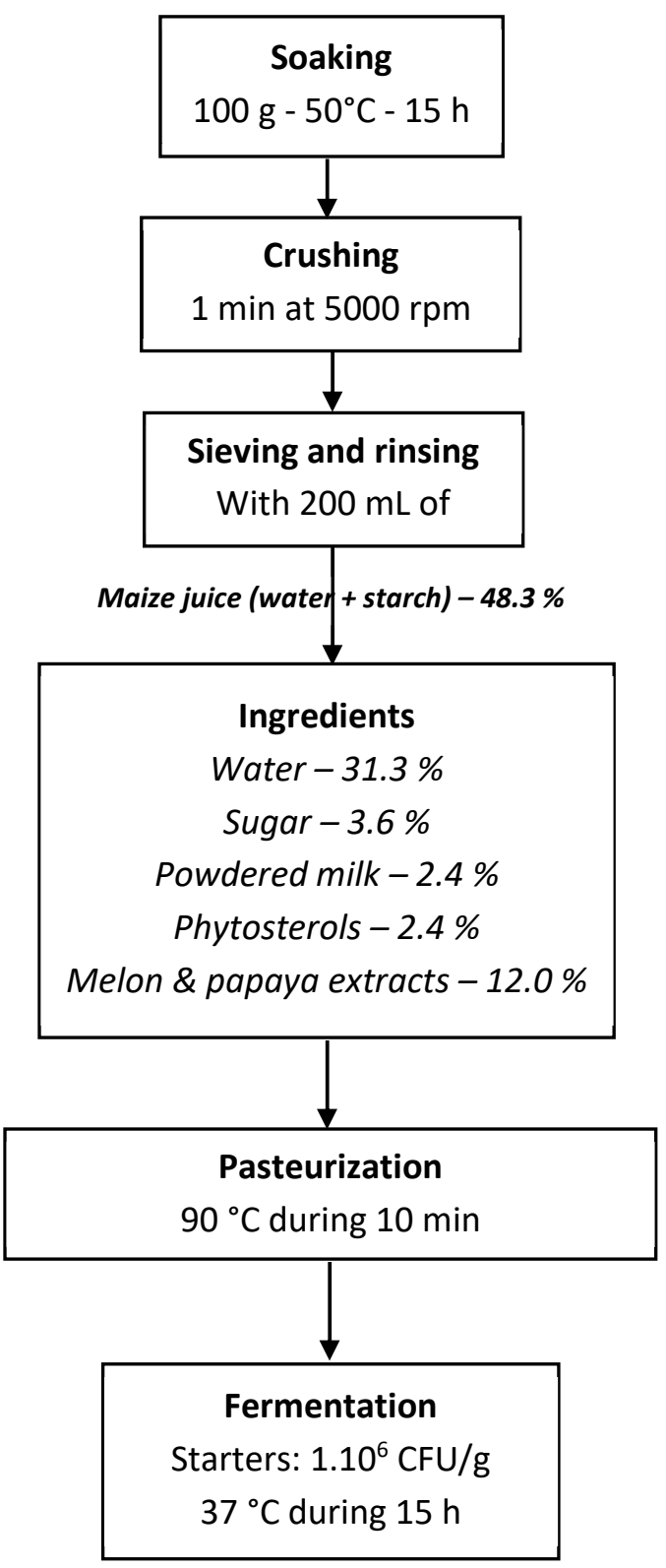




\section{Figure 2}

38
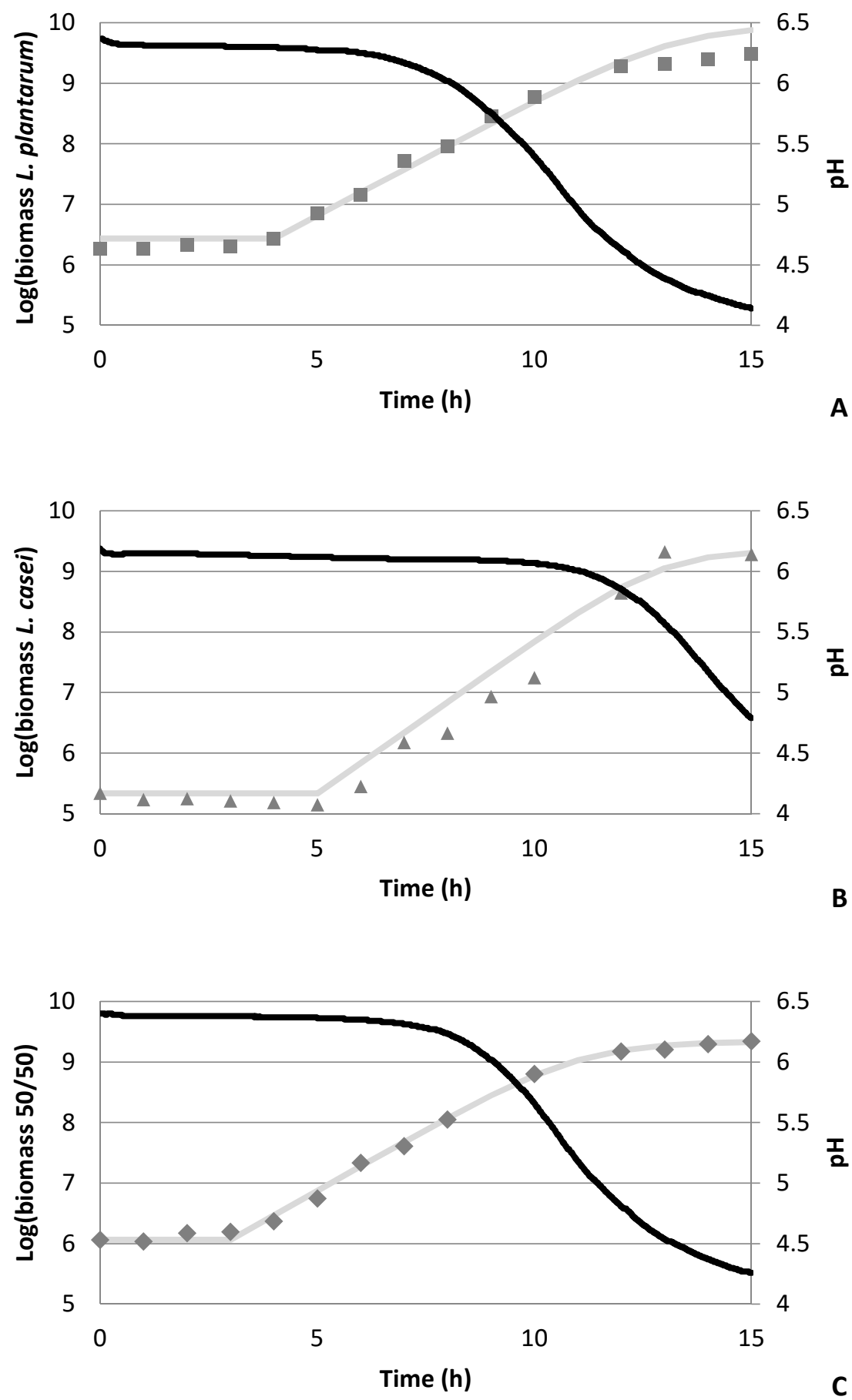
Figure 3

56

57

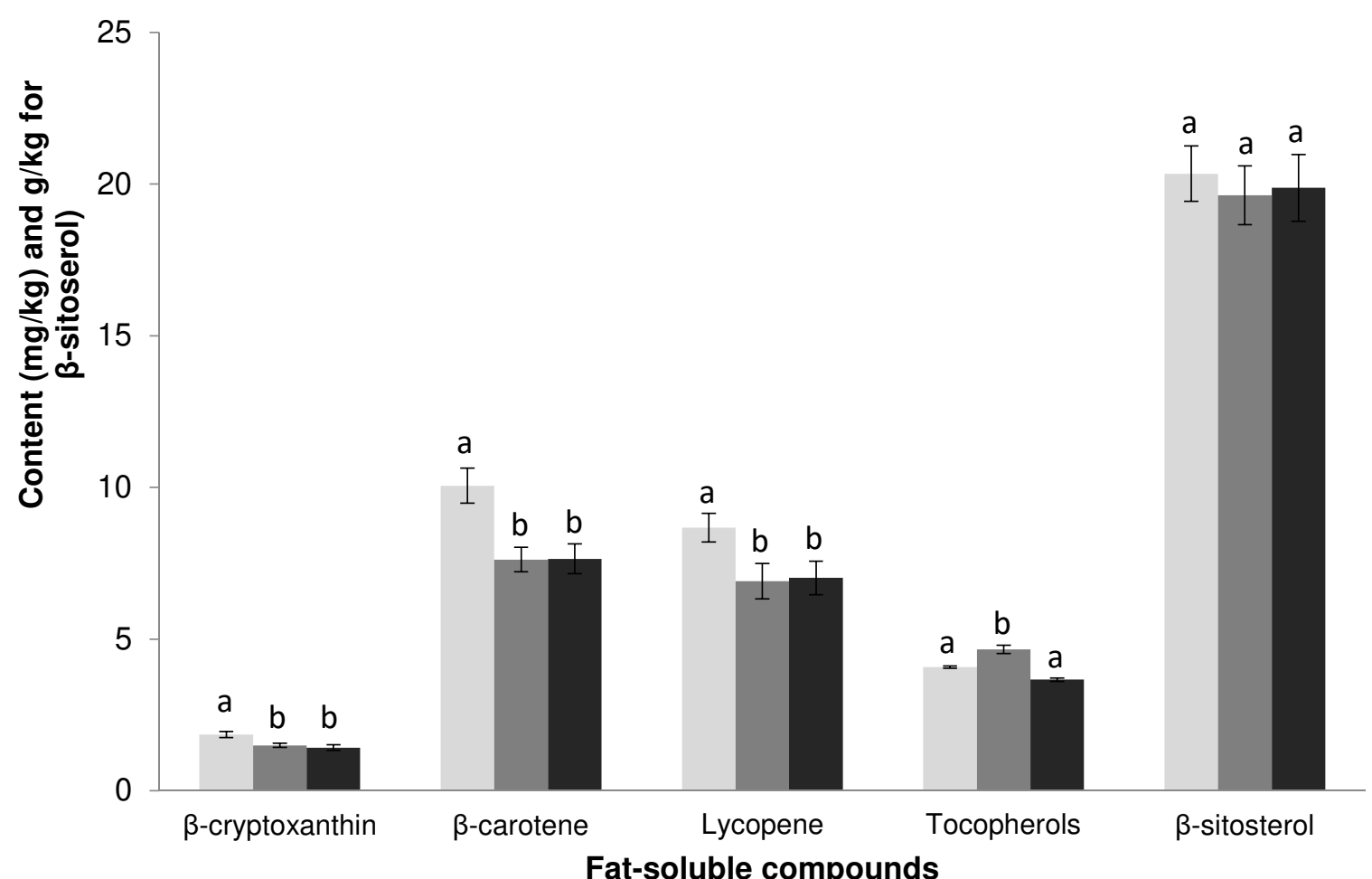

58 
1 Table 1. Fat-soluble phytomicronutrients and macronutrients content of the functional yogurt-

2 like product

\begin{tabular}{|c|c|c|c|}
\hline Phytomicronutrients & Content & \multirow{2}{*}{ Macronutrients } & \multirow{2}{*}{$\mathrm{g}$ per $100 \mathrm{~g}$} \\
\hline Carotenoids & $(\mathrm{mg} / \mathrm{kg})$ & & \\
\hline$\beta$-cryptoxanthin & $1.43 \pm 0.09$ & \multirow{6}{*}{$\begin{array}{l}\text { Proteins } \\
\text { Lipids } \\
\text { Fruits sugars } \\
\text { Glucose } \\
\text { Lactose } \\
\text { Fructose }\end{array}$} & $8.12 \pm 0.39$ \\
\hline$\beta$-carotene & $7.65 \pm 0.48$ & & $3.48 \pm 0.08$ \\
\hline Lycopene & $7.02 \pm 0.55$ & & $13.50 \pm 0.12$ \\
\hline Tocopherols & (mg/kg) & & $6.16 \pm 0.05$ \\
\hline$\alpha$-tocopherol & $0.34 \pm 0.04$ & & $1.08 \pm 0.01$ \\
\hline$\gamma$-tocopherol & $3.47 \pm 0.30$ & & $6.26 \pm 0.06$ \\
\hline Phytosterols & $(\mathrm{g} / \mathrm{kg})$ & $\begin{array}{r}\text { Added sugar } \\
(\text { Sucrose })\end{array}$ & $3.6 \pm 0.18$ \\
\hline$\beta$-sitosterol & $19.88 \pm 1.10$ & Starch & $2.34 \pm 0.29$ \\
\hline
\end{tabular}

3

Table 2. Parameters of strains' growth kinetics

\begin{tabular}{ccccc}
\hline Lactobacillus strains & $\begin{array}{c}\text { Specific growth rate } \\
\left(\mathbf{h}^{-1}\right)\end{array}$ & $\begin{array}{c}\text { Generation } \\
\text { time }(\mathbf{h})\end{array}$ & $\begin{array}{c}\text { Latency period } \\
(\mathbf{h})\end{array}$ & $\begin{array}{c}\text { Initial pH - } \\
\text { Final pH }\end{array}$ \\
\hline L. plantarum & $0.86^{\mathrm{b}}$ & 0.81 & 4 & 1.7 \\
\hline L. casei & $1.16^{\mathrm{a}}$ & 0.60 & 5 & 1.6 \\
\hline $\begin{array}{c}\text { L. plantarum / L. casei } \\
\mathbf{5 0 - 5 0}\end{array}$ & $0.94^{\mathrm{b}}$ & 0.74 & 3 & 1.9 \\
\hline
\end{tabular}

$7 \quad \mathrm{a}$ and $\mathrm{b}$ letters significantly different $(\mathrm{p}<0.05)$ 
